\title{
THE USE OF GEOGRAPHIC INFORMATION SYSTEMS IN PUBLIC SERVICES
}

\author{
Vladimir Senic* \\ Faculty of Hotel Management and Tourism, University of Kragujevac, \\ Vrnjacka Banja, The Republic of Serbia
}

With the further development of information and communication technology and a growing use of smart phones, the significance of Geographic Information System - GIS will indisputably continue to grow. This is supported by the fact that in the last decade geotechnology has been identified as one of the fastest growing technologies, along with biotechnology and nanotechnology. Even though GIS is increasingly being utilized in the Republic of Serbia, it appears that its use with some providers of public services is mainly deduced to showing spatial data with quite limited possibilities for a further analysis - which represents the essence of the use of GIS. The paper uses the examples of good practice in the sphere of the health system, public safety, rescue services and local government. The covered examples show that the use of the analytical component of GIS in everyday activities of the mentioned public services can make their work not only more transparent to the public, but considerably more efficient as well. This way, the analytical component of GIS enables decision-makers to improve the management of frequently limited available resources, while proving a higher level of the service quality to citizens as the final users.

Keywords: geographic information system (GIS), health system, emergency response, local government

JEL Classification: L80

\section{INTRODUCTION}

As J. T. Coppock and D. W. Rhind (1991, 21) suggest, there are rather few written traces on the beginnings of the geographic information system (GIS). Nevertheless, the first modern use of GIS

* Correspondence to: V. Senic, Faculty of Hotel Management and Tourism, Vrnjacka Banja, University of Kragujevac, The Republic of Serbia, Vojvodjanska bb, 36210 Vrnjacka Banja; e-mail: vsenic@kg.ac.rs can be associated with the Canadian government efforts made in the mid-1960s (Haklay, Antoniou, Basiouka, Soden \& Mooney, 2014, 11). This endeavor included the census of Canadian land resources in order to understand how the land was used at that time, and also to have a better idea on how to use inventoried land in the future. The mentioned project is considered to be the first GIS project, whereas the first use of the term GIS is associated with the project's director R. Tomlinson (Longley \& Batty, 2003 , 2). Interestingly enough, this GIS project did not 
have any capacity to visualize the data, but only to show alpha-numeric outcomes in the form of a table. In spite of this shortcoming, this approach utilized by $\mathrm{R}$. Tomlinson and his team was soon recognized by the Harvard Laboratory for Computer Graphics which has designed and developed a multi-purpose GIS platform - creating in that way the foundation for the development of the first GIS software based on a synergy between a digital map and data.

However, according to P. Longley, M. Goodchild, D. J. Maguire and D. W. Rhind $(2001,11)$ the main driving force for a further development of GIS occurred during the 1980s, when the hardware prices went down enough to support significant development of GIS software. At that time, a decent computer system -rather modest compared to modern computers could have been purchased for about $\$ 250,000$, and the appropriate software was available at the price of about $\$ 100,000$. Even at these prices, the benefits of GIS significantly overcame the costs. With a further decline in prices, computers became more available, whereas the GIS software market was growing at a steady pace, as a logical result of the fact that there was a growing community of those who understood the benefits of GIS.

Nowadays, the implementation of GIS is quite disseminated - ranging from its application in cadaster bureaus to the very sophisticated business applications intended for the needs of analyzing customers and their demographic characteristics. Therefore, it should not come as a surprise that defining GIS is not an easy task to do. Commonly, it can be heard that GIS has as many definitions as applications. Yet, one of the frequently used definitions suggests that GIS represents an organized set of hardware, software and processes devised to allow the saving, editing, managing, handling, analyzing, modeling and visualizing of spatially referenced data, with an objective to solve complex issues in planning and management (Voerkelius, Glavina, Specht-Mohl \& Schilcher, 2008, 14).

Although GIS is used at an advanced analytical level by some scientists and practitioners - mainly those whose work is connected to geography and related disciplines - it seems that scientific and practicing communities in the Republic of Serbia (RS) are relatively modestly conversant with the means of the implementation of the analytical capabilities of GIS when providing public services. The search of SCIndeks (Serbian Citation Index) reveals that there are only a few papers that deal with utilizing the analytical aspects of GIS in the context of proving public safety services, whereas such an advanced use of GIS is almost non-existent when speaking of the other types of public services. Therefore, the main objective of this paper is to highlight the analytical component of GIS as the tool that has an outstanding potential to improve the efficiency of some very important public service by using a set of the examples of good practice in the different fields of providing public services.

The next section of the paper will discuss the most frequent uses of GIS in RS today by the providers of public services. Thereafter, a number of the examples of good practice with respect to the analytical aspect of GIS in the domain of public health, public safety, rescue service, as well as local government are presented. In the final section of the paper, the most important implications, the shortcomings of the paper and new directions for further research will be stressed.

\section{THE USE OF GIS IN THE REPUBLIC OF SERBIA}

Even though the intensive utilization of GIS in developed countries is related to the 1980s, the more substantial use of GIS in RS has been occurring in the last 15 years. Certainly, the assumptions of an extensive use of GIS in RS existed during the 1990s (Jovanović, Đurđev, Srdić i Stankov, 2012, 172), which is supported by the fact that a course entitled "Geographic Information Systems" already existed within the Department of Spatial Planning at the Faculty of Geography - University of Belgrade. Unfortunately, the economic isolation of RS, among other negative effects, resulted in a delayed implementation of GIS on a greater scale in our country. Upon the lifting of the 
economic embargo, the most important providers of GIS software solutions significantly stepped up their presence in the Serbian market. That mainly resulted in the education of a wider auditorium of potential users and a better understanding of the capabilities that GIS offers in different fields.

Nowadays, GIS has become a tool that is mainly used in everyday work of many city cadasters and city planning bureaus throughout RS. Recognizing the benefits of GIS, many cities have commenced the implementation of their own "city GIS" projects. For the most part, "city GIS" involves web platforms with digital maps, with the option of showing different sets of thematic maps, as well as a certain level of interaction with available maps. In most cases, "city GIS" includes the maps of administrative units, streets and the address system, roads, natural resources, general urban plans, cadaster data and, in some instances, even the air quality in certain parts of the city.

At the national level, in compliance with the Infrastructure for Spatial Information in Europe Initiative (INSPIRE) guidelines, the Republic Surveying Authority has established the National Spatial Data Infrastructure (NSDI). The main goal of the NSDI is to create an integrated system of spatial data, while allowing users to access with ease various types of spatial data, regardless of whether its source is of a local, national or global character (Vlada Republike Srbije, 2010, 1). This certainly is a big step forward towards conducting various analyses or providing location-based services, especially if we speak of delivering a large number of different public services.

Nevertheless, an impression is that some providers of public services in RS either do not fully understand the importance of GIS for their everyday activities or simply do not have adequate human/technical resources for integrating GIS in their activities - in the majority of the cases it is a combination of both factors. Namely, if we speak of health services, public safety, or rescue services, it can be implied that the use of GIS for analysis or decision-making is at best very limited, with certain exceptions. On the other hand, even though the concept of "city GIS" exists in many Serbian cities, it seems that local governments do not recognize the numerous possibilities of GIS in the context of attracting investors or improving the business climate in their communities, thus being unable to create added value for investors through the use of the analytical component of GIS, although the conditions for this exist.

\section{THE USE OF GIS FOR PUBLIC HEALTH SERVICES}

A long tradition of spatial studies in public health goes back to the $19^{\text {th }}$ century (Setia, Singh, Mathur, Makkar \& Pal, 2017, 2). Numerous recent studies have utilized traditional tools for visualizing, as well as data research methods and their modeling that was taken from statistics and epidemiology. Simultaneously with the studies in the domain of spatial epidemiology, a number of other research efforts that were taking place were less within the paradigm framework common for natural sciences, but more within the context of social sciences, including above all the studies on health disparity and variations by regions that were taking into consideration not only health conditions, but also access to and the quality of the rendered health services. Certainly, what is common for both paths of research is the recognition that space and location are of significant importance.

In the previous years, we witnessed the frequent occurrence of epidemics and pandemics, such as the avian flu or A (N1 H1). Taking into consideration the fact that an epidemic outbreak can be followed in space, the application of GIS becomes apparent in the domain of improving public health and preventing the events that can lead to fatal consequences for the population's overall health, which has resulted in the appearance of geomedicine (Blatt, 2015, 102) and spatial epidemiology.

Spatial epidemiology can be defined as the analysis of the spatial occurrence of disease risks and incidence (Ostfeld, Glass \& Keesing, 2005, 328). This type of analysis allows the identification of the 
population groups with the relatively high levels of a predisposition for catching certain diseases and can significantly assist in isolating the potential source factors of an illness for further analysis. Spatial analysis can also be of great significance in the case of some types of disease that do not have epidemic roots, such as respiratory diseases and cancer. This is especially true when similar results are being confirmed at different times and in different locations, allowing for implications about the etiology of the given disease (www.who.int, 2017).

One of the good examples is a research study by L. A. Williams, C. M. Ulrich, T. Larson, M. H. Wener, B. Wood, P. T. Campbell, J. D. Potter, A. McTiernan, and A. J. De Roos $(2009,373)$, who did research in the correlation between living close to streets with heavy traffic and the condition of the immune system. The research focused on obese women in postmenopause - a population particularly at risk if exposed to the polluted air. The results of the study revealed that the women living up to 150 meters away from roads with heavy traffic have $21 \%$ fewer cytotoxic lymphocytes in comparison to the women who lived farther away from such roads. The authors of this study conclude that such results can have significant implications for a future policy on the use of the land that is near to heavy traffic spots. On the other hand, the next step that could be taken is that related to creating targeted campaigns focused on informing the population that already lives near heavy traffic locations about the importance of having more frequent health check-ups.

Another interesting use of GIS in the domain of health services is a consequence of the Internet's rapid growth. The dissemination of maps in the web environment can assist decision-makers to a great extent, especially when speaking of the prevention and control of, and reaction to the occurrence of certain diseases. As presented in the previous example, the phenomenon of the disease is closely related to the spatial and temporal factors. The Webbased GIS enables us not only to show data in real time, but also to present new information on a given disease in a dynamic manner. Therefore, it comes as no surprise that in the last twenty years the Internet has become an important medium for the public health institutions dealing with the overall health conditions, as well as for the general population demanding more pieces of information on the state of public health. It could be stated that the Internet has become the main technology for monitoring public health.

Data on the appearance (and spreading) of diseases are no longer reported exclusively through the official statements made by health institutions, but are more frequently so reported via the less formal channels that include anything from newspaper reports, blogs, chat rooms to the statistical analysis obtained from web searches. All these channels together create a brand new approach to understanding the overall state of public health that can be significantly different from what is presented by traditional means. These less formal means of informing significantly shorten the time needed for disease recognition, preventing the government authorities from covering up information on epidemics, while allowing a faster reaction to epidemic outbreaks.

Nowadays, web applications can search, categorize, filter and visually present on the map all the developments related to an epidemic occurrence and disease spreading in real time. A good illustration is the Health Map that is publicly available on the web portal (www.healthmap.org) for the purpose of informing on public health matters, which uses data from various sources in order to create an overview of the currently active infectious diseases at the global level. The sources from which the Health Map obtains pieces of information on epidemic outbreaks are of different confidence, varying from the information that can be found on Google News and ProMED to the official and credible information that comes from the World Health Organization. This web portal (www. healthmap.org) has over 100,000 users on a daily basis, including government health institutions, physicians and those who are planning international trips. Other similar systems include MediSys, Argus, EpiSPIDER, BioCaster and Wildlife Disease Information Node (Brownstein, Freifeld \& Madoff, 2009, 2154).

A particularly interesting application of the GISbased epidemiology was developed by Walgreens. 
Namely, the company has created The Walgreens Flu Index ${ }^{\mathrm{TM}}$ that is based on a number of purchased flu medications in over 8,000 Walgreens' stores across the United States. Based on the number of the purchased medications, Walgreens generates the maps on a weekly basis that show which segments of the country's population are the most affected and even more significantly it does so faster than the Center for Disease Control and Prevention, whose main objective is to inform the population about health risks as early as possible.

Nevertheless, in the medical context, GIS is not only used for studying the epidemiology and spread of diseases, but also for representing any system that has a spatial component, including the processes that occur within the body of an individual patient (ESRI, 2008a, 5). This is especially true in the case of the bio-medical imaging that shows organs at a micro level. In that respect, GIS based on vector images can be used successfully to examine the blood flows in micro-vascular networks (Roth \& Kiani, 1999, 44).

\section{THE USE OF GIS BY PUBLIC SAFETY SERVICES}

Services dedicated to maintaining public safety (such as the police, the judicial system and other relevant institutions) are faced with numerous tasks and challenges in their daily efforts to protect human lives and property. Given the fact that almost every task they are facing has a spatial component, GIS presents itself as an invaluable resource for the daily activities of these public safety services. The GISenabled fast access to data and their processing and visualizing allow for a quick and efficient allocation of the needed resources. For public safety, data on the crime location, an incident, a suspect or a victim are of utmost importance in determining the means and scale of reaction. Furthermore, GIS may be utilized for generating information of critical importance for response units, which have to react at the moment's notice. Nowadays, modern public safety services cannot be imagined without the use of GIS technologies. Response teams are not only able to react faster to critical incidents, but they are also able to achieve the highest possible levels of efficiency in the use of available resources (ESRI, 2006, 4).

The backbone of every analysis begins with entering the exact locations where human lives and property have been endangered. Based on such data, we can find out a great deal about the type and occurrence of such events. A quite interesting example where GIS has been used to record criminal activities is the CLEAR Map of the Chicago Police Department (CPD). Namely, the CPD has created a web portal that can assist citizens to track the criminal activity in their neighborhoods.

This web-based application is publicly available and allows the citizens of Chicago to search the CPD's database that contains all of the recorded events related to public safety. The application allows the citizens to view the thematic maps categorized by the type of criminal offense. The database itself contains the records of all of the events in the last year that can be searched by the time periods of $90,180,270$ and 365 days, whereas the data are updated on a daily basis. By utilizing the GIS software and other technologies, the CLEAR Map's database can generate the maps that show almost all different variations of the location where an offense was committed or other relevant pieces of information, where every piece of data can simultaneously be shared with officers in the Command Center, as well as with the citizens, via the web portal. Such visualizations are useful and very effective additions to those rendering public safety services, allowing those in charge to identify, discuss and note the patterns in the domain of public safety.

The true value of one such system in terms of public safety can be seen through the cases in which GIS assists to establish where next crime will occur, based on historic data. One such example is a Los Angeles case dating back in 1998 (Geggie, 1999, 111). Namely, detectives were looking into a series of three robberies, where the offender attacked the victims and robbed them as they were walking to their parked cars. The mentioned attacks occurred in three completely different locations within the range of several kilometers. 
The idea was to use the historical data, as well as the way in which the crime was committed, in order to predict the time and the location of the next attack. This was done by mainly relying on the statistical methodology that used the mean values $(\mu)$ and the standard deviation $(\sigma)$ of the attacks. This methodology took into account the times of the attacks and the locations where they had occurred (shown as dots in Figure 1). Assuming the normal distribution principle, it was determined that there was an $68 \%$ probability (i.e. within $1 \sigma$ ) that the next attack would occur between January $25^{\text {th }}$ and February $6^{\text {th }}$, in a time period between 20:45 and 23:45, in some of the locations marked with the smaller rectangle. By using the same logic, there was a $95 \%$ probability (within $2 \sigma)$ that the next attack would occur in longer time spans and in the locations that were marked within the larger rectangle, as is shown in Figure 1.

The fourth attack occurred within the expected time and location frameworks that had been predicted based on the first three attacks. Following the fourth attack, new predictions were made and the police units were distributed in the field with an objective to capture the offender. During the fifth attack, the suspect was spotted, but after the chase the criminal managed to escape. Even though the offender ran away, the objective was partially achieved given the fact that after the last attack there were no similar incidents in that part of the city.

\section{THE USE OF GIS BY RESCUE SERVICES}

Emergency rescue services are responsible for protecting human lives and property, but quite often they are faced with limited resources in the context of the people and equipment. RS is no exception to this rule. Namely, there is a major shortage of firemen according to the European standards, RS should have about 7,000 firemen in service, but instead there are currently only about 3,100 in service („,Koliko Srbiji nedostaje vatrogasaca?", 2016).

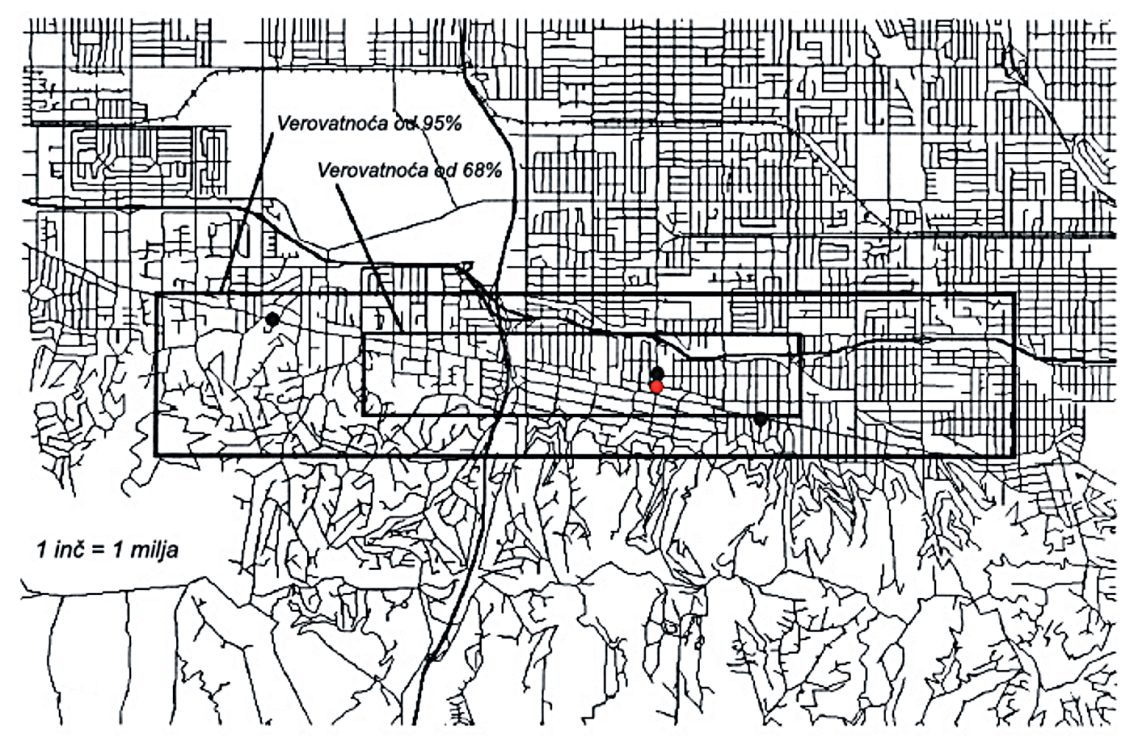

Figure 1 Map of LA where attacks occurred 
Firefighting is far more than mere reaching the location of fire. Nowadays, firefighting assumes a holistic approach to a given situation and possible scenarios. GIS offers a set of tools for work with tactical, location-based information, such as - what it is in the immediate surroundings that may have an effect on the course of action. In that sense, urban environments pose a special challenge (Forkuo \& Quaye-Ballard, 2013, 32). Facilities including schools, shopping malls, warehouses with dangerous substances, factories or gas stations, may additionally complicate intervention in the field and determine its course. Access to such information while the response units are on the way to the location of an accident allows firefighters to secure the area faster and more effectively, taking into consideration possible threats to the population and the units in the field.

Indeed, the incoming information can be "fed" into the GIS application that can provide an overview of the potential threats that are in the immediate vicinity of an accident in real time, as is shown in Figure 2(a). For instance, sparks from a nearby electrical substation can ignite the flammable gases already present in the air, eventually causing an explosion of a larger scale.

The unique value of such an "intelligent tool" for rescue service is reflected in the fact that it allows those in charge to make an estimate of the number of the people living near the endangered zone. That is possible based on the census data that are already in the GIS database. Although such estimates may not have perfect accuracy, they do enable the planning of certain activities, such as the evacuation of certain city neighborhoods. It is particularly important to stress that such a GIS facilitates the prompt anticipation of events and taking all the necessary measures for minimizing and eliminating the unwanted effects for the local population (Andrienko \& Andrienko, 2007, 901), as is seen in Figure 2(b).

Another good illustration is a study by T. J. Cova $(1999,53)$, who has developed a "tool" that enables local communities to assess the probability of traffic jams during evacuation efforts. The application uses the GIS database that contains information on the dissemination of the population within a community, as well as the streets network. The final result is the "vulnerability map" that points to potential trafficrelated bottleneck points during evacuation. Given the fact that the scale of an accident cannot be determined in advance, this method is based on the principle of the worst possible scenario in a given location.

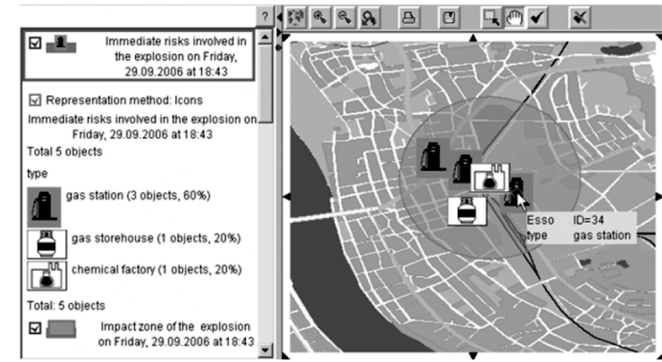

(a)

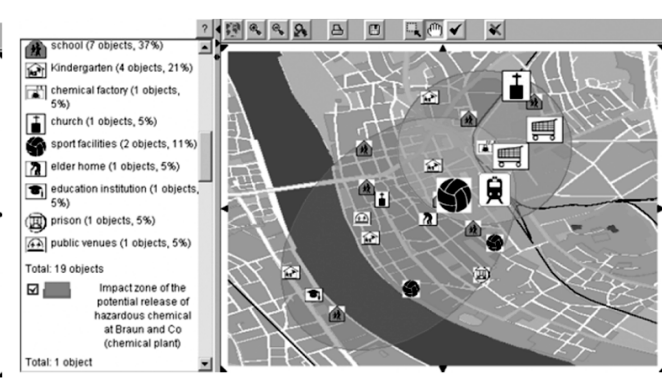

(b)

Figure 2 The potential sources of risk in the immediate surroundings

(a) The map shows the other potentially dangerous facilities that are in an immediate vicinity;

(b) The map shows which objects will be under a direct impact in the case of some of the potential scenarios - specifically, the emission of chemicals from a local factory 
We can assume that a certain neighborhood is threatened by a forest fire and that evacuation is necessary. Furthermore, we can assume that only one vehicle is needed to evacuate the entire family from one household. If the households are located in a dead-end street, then all inhabitants have to use the same street exit. The method used by T. J. Cova (1999) is designed to take into account the entire network of roads/streets so as to determine the bottleneck - the section that will suffer the greatest traffic congestion during evacuation. In the neighborhood with a dense network of roads/streets, traffic will flow towards several exit options, minimizing the bottleneck effect. However, densely populated areas with the limited $\mathrm{road} / \mathrm{street}$ infrastructure can lead to serious issues during evacuation, if the situation demands the prompt evacuation of the entire area.

Figure 3 shows the map of one part of Santa Barbara, California. The streets are displayed in different colors, depending on the bottlenecks, based on the previously explained method used by T. J. Cova (1999). The streets are assigned different colors, depending on the expected number of the vehicles that should go through the critical bottlenecks during the evacuation effort, taking into consideration the worst possible scenario. The dark-colored locations represent the places where it is estimated that over 500 people will pass during evacuation, thus creating potentially dangerous standstills, wasting precious evacuation time.

By analyzing such maps, firefighters (and other rescue services) can have an overview of the most critical locations during the evacuation effort and consequently plan to dispatch the units in those spots so as to facilitate the flow of traffic. On the other hand, such analyses allow for the better planning of the traffic infrastructure that can take into account bottlenecks and try to minimize their number.

\section{THE USE OF GIS BY LOCAL GOVERNMENTS}

One of the most frequent uses of GIS can be found in the domain of local government (Campbell \& Masser, 1992, 529). City managers make decisions on a daily basis that directly or indirectly have an impact on the quality of the life of every single citizen that works and resides in a given city or community. Nevertheless, citizens are quite aware of the fact that wrong decisions made by local authorities may have a negative effect on the quality of their lives - starting from traffic jams to protecting the natural environment. Therefore, citizens start to demand that decisions made by local governments should

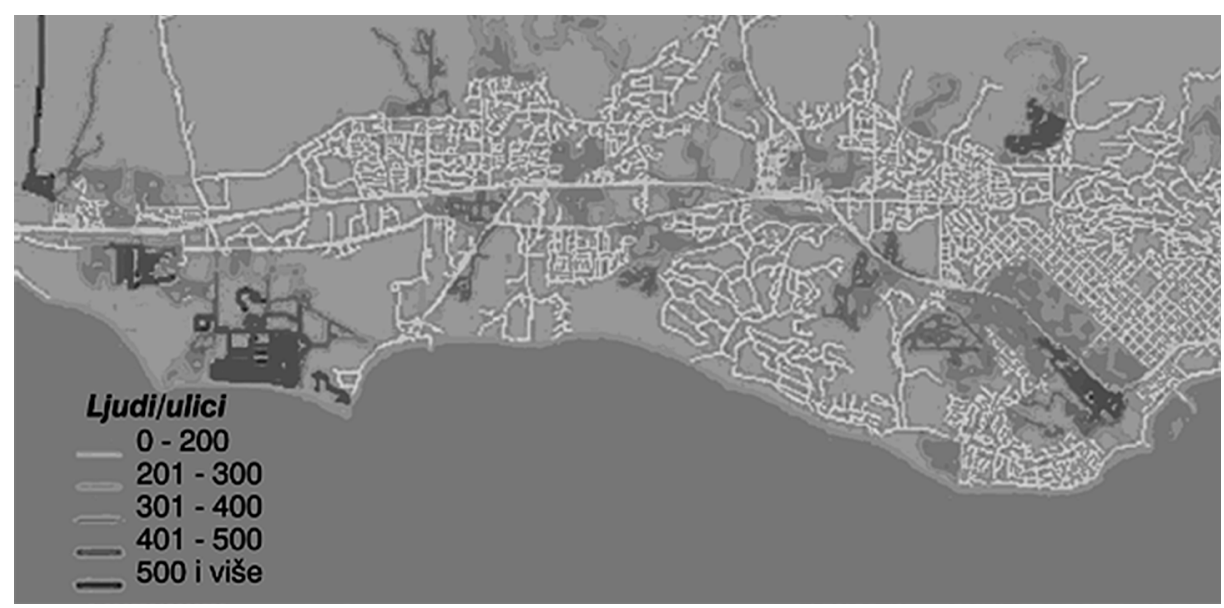

Figure 3 The map of the street bottlenecks in Santa Barbara, California 
be justified and supported by adequate data. In that way, not only will the risk of making wrong decisions be minimized, but non-functional and often financially unjustified projects will be prevented from commencing.

In fact, citizens increasingly demand that the offered actions should result in improved efficiency in solving their problems, generating sustainable value, a further enhancement of the community's development capacities, as well as the better management of the city's infrastructure and resources. Hence, it comes as no surprise that a growing number of local governments (Jacoby, Smith, Ting \& Williamson, $2002,305)$ and utility companies operating at the city level invest in GIS and in building databases - whose synergy can significantly facilitate decision-making.

The fact is that those who create policies at a local/ regional level have a talent for suggesting rather complicated solutions. Prior to the introduction of GIS, the costs of testing such solutions and their evaluation were quite high in terms of money, effort and time. In other words, GIS has enabled the testing of complex solutions through a set of scenarios using data from the real world and their implementation starts only after it has been determined that a particular solution is acceptable for all stakeholders.

The general acceptance of GIS technologies implies the value that this tool has in the process of reaching many important decisions. Indeed, nowadays, GIS is used in almost all aspects of planning a community's development or following the trends occurring within it. City architects and cadasters need as detailed information as possible on the classification of land parcels and available land resources in specific parts of a city or a region. Civil engineering needs to plan a network of roads, define the building of timeframes and forecast all costs associated with road construction. Also, it should not be forgotten that all large-scale infrastructure installations, such as sewage, the water system or telecommunication, demand spatial data in order to establish efficient maintenance or a faster response in the case of issues or when planning to add new users to the existing service network. Numerous public services have recognized the possibilities that GIS offers. Thanks to GIS, many spatial analyses are conducted in order to attract new and support the existing businesses that, in turn, create new jobs - thus strengthening a city's tax potential, or in order to improve the planning and implementation of large-scale works.

In addition to the said, the synergy between the increasingly more available Internet, on the one hand, and digital maps, on the other, defines the new types and levels of the services that local authorities can offer to their citizens. Generally, the services based on the GIS technologies offered by local governments can be classified into the following three categories: a) the services aimed at business users, b) the services aimed at the local population, and c) the services aimed at other governing bodies. In the next section of the paper, only the first category will be briefly covered.

\section{Local Government Services Aimed at Business Users}

These types of services are usually related to fostering economic development, information on land use in certain urban zones, the efficient processing of various requests and the issuance of permits. Potential investors can access all relevant data on a $24 / 7$ basis, locate the city areas where the construction of manufacturing facilities, shopping malls or residential/office buildings is permitted, or have the visualization and analyze the demographic or economic data collected from the last population census for certain city areas.

In the domain of supporting economic development, GIS technology is used dominantly as an efficient way to attract new investors. In fact, the mere existence of GIS in a given city can be said to already be creating a favorable climate and a desirable location for hi-tech companies. However, in order to attract additional capital, or to convince the existing companies not to relocate their production facilities, the GIS of a local government needs to be completely adjusted to the business needs of the investors themselves. For numerous investors, seeking efficiency leads 
towards not only finding an optimal location, but also towards obtaining an absolutely transparent picture of a given potential location. Today's investors prefer getting a complete image, taking into consideration the traffic and telecommunication infrastructures, the community's image, the skills of the local labor force, the market size, sustainability and plans for a further development of local communities.

Hence, in order to remain competitive, many cities (and entire regions as well) develop their own GIS infrastructures that should be able to give answers to all of these - and many other - questions to the prospective investors. The Savannah Economic Development Authority (SEDA) represents an example of good practice. SEDA was founded in the mid-1990s, with an objective to improve the living standard of the population that resides in the Savannah and Chatham counties, Georgia, USA, through stimulating economic development by attracting investment capital, generating new jobs and providing an adequate support to the companies that had already been located in that region.

SEDA is certainly aware of the fact that, in the competitive environment that is becoming increasingly tougher on a daily basis, it is impossible to offer prospective investors the papers with a list of available real estate and their square footage. To investors, it is of vital importance to know where the potential site is exactly located - how far from the port, the train station, the highway or the local airport. Above all, investors want to know all of these things even prior to making the initial contact with the local authorities.

Understanding these demands, SEDA has introduced a GIS portal (http://www.savannahsitesearch .com/) with a database containing all of the available manufacturing facilities, office spaces and parcels that range between $500 \mathrm{~m}^{2}$ to 250 hectares. At every moment, SEDA has at its disposal over 150 real estate locations that it can offer investors. SEDA offers its potential clients all the available data via the Internet portal, and much more beyond that. Indeed, through the GIS use, a connection between spatial and nonspatial data has been established, thus creating an efficient geo-database for managing resources, while shortening the search time. Clients can conduct their search as per available real estate, select the one that matches their need and perform various types of demographic and business analyses (ESRI, 2008b, 2). In addition to this, SEDA has the capability of overlooking all changes in real time and offering its clients the data that are always up-to-date.

A study on the economic impact SEDA had on the development of the local economy revealed that, in the period between 1996 and 2007, in collaboration with the state and local partners, SEDA had helped to create 15,320 new jobs and had generated $\$ 1.8$ billion in investments (SEDA Annual Report, 2007). The study also showed that without these jobs mainly attracted by SEDA, the region would not have reached this level of development until as late as 2020.

\section{CONCLUSION}

The main contribution of this paper is reflected in the fact that, in RS, there are only a few studies of the use of analytical GIS in the domain of public services. Through the examples of good practice, the paper stresses an important role that analytical GIS can play for different providers of public services, given the fact that the numerous activities that they perform on a daily basis and the issues that they are faced with both have a pronounced spatial component. On the other hand, it should not be forgotten that, nowadays, providers of many public services are under growing pressure to deliver the best services possible to the general public with the limited time, financial, operational or human resources. In order to do so, they turn to GIS as an indispensable technology that allows those who plan and deliver public services to achieve improved information processing, design better decision-making processes and reduce overall costs, while simultaneously improving the quality of life in their communities.

Certainly, one of the shortcomings of this paper is related to the fact that it does not provide a more precise overview of the current state in terms of the 
utilization of analytical GIS among the mentioned providers of public services in RS. Namely, certain assumptions were made primarily on the publicly available data, which does not exclude a possibility that certain types of analytical GIS are carried by the providers of public services addressed in this paper. In fact, this shortcoming provides one possible direction for future research, and that is the study of the level of the integration of GIS and its analytical capacities into the day-to-day activities of the analyzed providers of public services in RS. Such a study would allow for a much better understanding of the current state when the analytical component of GIS is concerned, and identify future steps for a faster adoption of this technology, with the end goal of creating new services and also improving the quality and transparency of the already existing public services for citizens.

\section{REFERENCES}

Andrienko, N., \& Andrienko, G. (2007). Intelligent visualisation and information presentation for civil crisis management. Transactions in GIS, 11(6), 889-909. doi:10.1111/j.1467-9671.2007.01078.x

Blatt, A. J. (2015). Geospatial Medicine. In Health, Science, and Place (pp. 101-110). Geotechnologies and the Environment, vol 12, Springer Cham. doi. org/10.1007/978-3-319-12003-4_9

Brownstein, J. S., Freifeld, C. C., \& Madoff, L. C. (2009). Digital disease detection-harnessing the Web for public health surveillance. New England Journal of Medicine, 360(21), 2153-2157. doi:10.1056/NEJMp0900702

Campbell, H., \& Masser, I. (1992). GIS in local government: some findings from Great Britain. International Journal of Geographical Information Science, 6(6), 529-546. doi:10.1080/02693799208901933

Coppock, J. T., \& Rhind, D. W. (1991). The history of GIS. Geographical information systems: Principles and Applications, 1(1), 21-43.
Cova, T. J. (1999). GIS in emergency management. In P. A. Longley, M. F. Goodchild, D. J. Maguire, \& Rhind, D. W. Geographical Information Systems: Principles, Techniques, Applications, and Management (pp. 845-858). New York, NY: John Wiley \& Sons.

ESRI. (2006). Law Enforcement: GIS Best Practices. Redlands, CA, USA: ESRI Press.

ESRI. (2008a). Geography Matters. Redlands, CA, USA: ESRI Press.

ESRI. (2008b). Case Study: ESRI GIS Software Enables SEDA to Attract New Business to Savannah. Retrieved November 10, 2017, from www.esri.com/library/casestudies/seda. pdf

Forkuo, E. K., \& Quaye-Ballard, J. A. (2013). GIS based fire emergency response system. International Journal of Remote Sensing and GIS, 2(1), 32-40.

Geggie, P. (1999). Mapping and Serial Crime Prediction. In N. LaVigne, \& J. Wartell (Eds.). Crime Mapping: Case Studies - Success in the Field (109-116). Washington, DC: Police Executive Research Forum.

Haklay, M., Antoniou, V., Basiouka, S., Soden, R., \& Mooney, P. (2014). Crowdsourced Geographic Information Use in Government. New York, NY: World Bank Publications.

Jacoby, S., Smith, J., Ting, L., \& Williamson, I. (2002). Developing a common spatial data infrastructure between State and Local Government - An Australian case study. International Journal of Geographical Information Science, 16(4), 305-322. doi:10.1080/13658810110096001

Jovanović, V., Đurđev, V., Srdić, Z., \& Stankov, U. (2012). Geografski informacioni sistemi. Beograd-Novi Sad, RS: Univerzitet Singidunum i Univerzitet u Novom Sadu.

Longley, P., \& Batty, M. (2003). Advanced Spatial Analysis: the CASA Book of GIS. Redlands, CA, USA: ESRI, Inc.

Longley, P., Goodchild, M., Maguire, D. J., \& Rhind, D. W. (2001). Geographic Information Systems and Science. New York, NY: John Wiley \& Sons.Inc.

Ostfeld, R. S., Glass, G. E., \& Keesing, F. (2005). Spatial epidemiology: an emerging (or re-emerging) discipline. Trends in Ecology \& Evolution, 20(6), 328-336. doi:10.1016/j. tree.2005.03.009 
Roth, N. M., \& Kiani, M. F. (1999). A 'geographic information systems' based technique for the study of microvascular networks. Annals of Biomedical Engineering, 27(1), 42-47.

SEDA. (2007). Annual Report: Staff and Educational Development Association. Retrieved September 20, 2017, from http://www.seda.org/savannah/17/about-seda.html

Setia, S., Singh, S., Mathur, A., Makkar, D. K., \& Pal, V. (2017). Health care and Geomedicine: A Review. World Journal of Environmental Biosciences, 6(1), 1-3.

Vlada Republike Srbije (2010). Strategija uspostavljanja infrastukture prostornih podataka u Republici Srbiji za period od 2010. do 2012. godine. Preuzeto 24. decembar 2017, sa http://www.geosrbija.rs
Voerkelius, U., Glavina, J., Specht-Mohl, C. i Schilcher, M. (2008). Upravljanje zemljištem/ katastar u Srbiji - GIS priručnik za lokalne samouprave u Srbiji. Beograd, RS: Stalna konferencija gradova i opština, Republički geodetski zavod, Nemačka tehnička saradnja, Kancelarija za upravljanje zemljištem/katastar u Srbiji.

Williams, L. A., Ulrich, C. M., Larson, T., Wener, M. H., Wood, B., Campbell, P. T., Potter, J. D., McTiernan, A., \& De Roos, A. J. (2009). Proximity to traffic, inflammation, and immune function among women in the Seattle, Washington, area. Environmental Health Perspectives, 117(3), 373-378. doi:10.1289/ehp.11580

World Health Organization. Retrieved November 5, 2017, from http://www.who.int

$$
\begin{aligned}
& \text { Received on } 4^{\text {th }} \text { December 2017, } \\
& \text { after revision, } \\
& \text { accepted for publication on } 22^{\text {nd }} \text { December } 2017 . \\
& \text { Published online on } 29^{\text {th }} \text { December } 2017 .
\end{aligned}
$$

Vladimir Senic is an Associate Professor at the Faculty of Hotel Management and Tourism in Vrnjacka Banja - University of Kragujevac, the Republic of Serbia. The main focus of his scientific work is related to the topics of the service quality, customer satisfaction, customer loyalty and the use of geographic information systems in everyday business activities of service companies. 


\title{
PRIMENA GEOGRAFSKIH INFORMACIONIH SISTEMA U JAVNIM USLUGAMA
}

\author{
Vladimir Senić* \\ Fakultet za hotelijerstvo i turizam u Vrnjačkoj Banji Univerziteta u Kragujevcu
}

Sa daljim razvojem informaciono-komunikacionih tehnologija i sve većim korišćenjem pametnih telefona, značaj geografskih informacionih sistema (GIS) će nesumnjivo nastaviti da raste. Tome u prilog ide i činjenica da je u poslednjoj deceniji geotehnologija označena kao jedna od najbrže rastućih tehnologija, pored biotehnologije i nanotehnologije. Iako se GIS sve više primenjuje u Republici Srbiji, čini se da je njegova upotreba kod pojedinih pružaoca značajnih javnih usluga svedena samo na prikazivanje prostornih podataka sa limitiranim mogućnostima za analiziranje istih - što predstavlja suštinu upotrebe GIS-a. Svrha ovog rada je da ukaže na izuzetan analitički potencijal koji GIS ima u oblasti pružanja i unapređenja različitih usluga od javnog interesa. U radu su korišćeni primeri dobre prakse u domenu zdravstvenog sistema, održavanja javnog reda i mira, spasilačkih službi i lokalne uprave. Navedeni primeri pokazuju da korišćenje analitičke komponente GIS-a u svakodnevnom radu pomenutih službi može učiniti njihov rad transparentnijim za javnost i znatno efikasnijim. Na taj način, analitička komponenta GIS-a omogućava donosiocima odluka da racionalnije upravljaju limitiranim raspoloživim resursima, pritom pružajući veći stepen kvaliteta usluge građanima.

Ključne reči: geografski informacioni sistemi (GIS), zdravstvo, spasilačke službe, lokalna uprava

\section{JEL Classification: L80}

\section{UVOD}

Kako J. T. Coppock i D. W. Rhind $(1991,21)$ sugerišu, postoji malo pisanih tragova o tome kako je zaista nastao geografski informacioni sistem (GIS). Ipak, smatra se da se prvi iskoraci $\mathrm{u}$ domenu moderne primene GIS-a mogu pripisati inicijativi Kanadske

* Korespondencija: V. Senić, Fakultet za hotelijerstvo i turizam u Vrnjačkoj Banji Univerziteta u Kragujevcu, Vojvođanska bb, 36210 Vrnjačka Banja, Republika Srbija; e-mail:vsenic@kg.ac.rs
Vlade sredinom 60-ih godina XX-og veka (Haklay, Antoniou, Basiouka, Soden \& Mooney, 2014, 11). Ovaj poduhvat je obuhvatio popis svih zemljišnih resursa Kanade kako bi se sagledalo trenutno korišćenje, ali i moguća buduća namena inventarisanog zemljišta. Pomenuti projekat se smatra "prvim GIS-om" (Longley \& Batty, 2003, 2). Ovaj najraniji GIS nije imao mogućnost bilo kakvog vizuelnog prikaza, i mogao je samo da predstavi numeričke output-e u tabelarnoj formi. Međutim, pristup koji je koristio R. Tomlinson je ubrzo bio prepoznat od strane Laboratorije 
za kompjutersku grafiku i prostornu analizu Univerziteta Harvard - koja je razvila opštenamenski GIS - i na taj način utemeljila osnove za razvoj prvog GIS software-a, koji se zasnivao na sinergiji digitalne karte i podataka.

Ipak, prema P. Longley-u, M. Goodchild-u, D. J. Maguire-u i D. W. Rhind-u (2001, 11), podsticaj za dalji razvoj GIS-a dogodio se tokom 1980-tih godina, kada su cene hardware-a pale na nivo koji je mogao da podrži značajniji razvoj software industrije i pojavu jeftinijih aplikacija. U to vreme kompjuterski sistem, skromniji u performansama od današnjih PC računara, mogao se nabaviti za oko 250.000 dolara, dok je odgovarajući software koštao oko 100.000 dolara. Čak i po ovim cenama, koristi od GIS-a - kao i odluke koje je bilo moguće doneti sa novim alatima - bitno su prevazilazile troškove. Sa daljim padom cena, računari su postajali sve dostupniji, dok se tržište za GIS software uvećavalo iz dana u dan, kao logična posledica činjenice da je zajednica onih koji su shvatili prednosti ove tehnologije postajala sve brojnija.

Danas je primena GIS-a rasprostranjena - od korišćenja u geodetskim zavodima i katastrima, do sofisticiranih poslovnih aplikacija za potrebe analize potrošača i njihovih demografskih karakteristika. Shodno tome, utvrđivanje jedinstvene definicije GIS-a nije lak posao. Neretko se može čuti da GIS ima onoliko definicija koliko i primena. Ipak, jedna od često citiranih definicija navodi da GIS predstavlja organizovan skup računarske opreme, programa i postupaka koji su osmišljeni tako da omoguće snimanje, editovanje, upravljanje, rukovanje, analizu, modeliranje i prikaz podataka sa prostornom referencom, a u cilju rešavanja složenih problema u planiranju i upravljanju (Voerkelius, Glavina, SpechtMohl \& Schilcher, 2008, 14).

Iako se GIS na analitički naprednom nivou koristi od strane dela naučne i stručne javnosti - a tu se prevashodno misli na one koji gravitiraju ka geografiji i srodnim disciplinama - čini se da je naučna i stručna javnost u Republici Srbiji (RS) relativno skromno upućena u načine implementiranja analitičkih mogućnosti GIS-a prilikom pružanja javnih usluga. Pretraga indeksne baze SCIndeks-a ukazuje da postoji svega nekoliko radova koji obrađuju tematiku analitičke upotreba GIS-a u kontekstu održavanja javnog reda i mira, dok ostali aspekti pružanja javnih usluga gotovo da nisu ni zastupljeni kada je u pitanju napredna analitička primena GIS-a.

Stoga, cilj ovog rada je da istakne analitičku komponentu GIS-a kao alata koji poseduje izuzetan potencijal da unapredi efikasnost $u$ radu pojedinih vrlo značajnih javnih službi i to kroz set primera dobre prakse $u$ različitim domenima pružanja javnih usluga.

U radu će biti ukazano na načine kako se danas najčešće koristi GIS u RS od strane ponuđača javnih usluga. Nakon toga, slede primeri konkretne primene analitičkog aspekta GIS-a u domenu zdravstva, održavanja javnog reda i mira, spasilačkih službi, odnosno na nivou lokalne uprave. Konačno, biće ukazano na najbitnije implikacije, nedostatke rada, kao i moguće pravce daljeg istraživanja.

\section{UPOTREBA GEOGRAFSKIH INFORMACIONIH SISTEMA U REPUBLICI SRBIJI}

Iako se intenzivnija upotreba GIS-a u razvijenim zemljama sveta vezuje za 80-te godine XX-og veka, u RS se GIS u značajnijoj meri koristi tek u poslednjih 15 godina. Svakako, pretpostavke za rasprostranjeniju upotrebu GIS-a u RS je postojala i tokom 1990-ih (Jovanović, Đurđev, Srdić i Stankov, 2012, 172), čemu ide $\mathrm{u}$ prilog činjenica da je $\mathrm{u}$ to vreme već postojao predmet Geografski informacioni sistemi u okviru Katedre za prostorno planiranje na Geografskom fakultetu Univerziteta u Beogradu. Nažalost, ekonomska izolovanost RS, pored svih drugih negativnih efekata, za rezultat je imala i kašnjenje $\mathrm{u}$ implementaciji GIS-a u značajnijem obimu u RS. Nakon ukidanja ekonomskih sankcija, najpoznatiji ponuđači GIS software rešenja, značajno intenziviraju svoje prisustvo na tržištu RS. To je primarno rezultiralo $u$ edukaciji šireg kruga potencijalnih korisnika i boljem razumevanju mogućnosti koje GIS pruža u različitim oblastima. 
Danas je GIS postao alat koji se dominantno koristi u svakodnevnom radu mnogobrojnih katastarskih službi, odnosno gradskih direkcija za urbanizam širom RS. Uvidevši benefite GIS-a, mnogi gradovi su krenuli u realizaciju sopstvenih ,gradskih GIS-ova“. U najvećem broju slučajeva "gradski GIS“ podrazumeva web-portale sa digitalnim kartama, pri čemu postoji mogućnost prikaza različitih setova temarskih karata, ali i određen stepen interakcije sa dostupnim kartama. U najvećem broju slučajeva, "gradski GIS“ sadrži kartografski prikaz administrativnih jedinica, ulica i adresnog sistema, puteva, priorodnih resursa, zatim generalne urbanističke planove, katastarske podatke, čak i prikaz kvaliteta vazuha na pojedinim lokacijama u gradu.

Na republičkom nivou, Republički geodetski zavod je u skladu sa smernicama Inicijative za kreiranje infrastrukture za prostorne informacije u Evropi (Infrastructure for Spatial Information in Europe Initiative - INSPIRE) uspostavio Nacionalnu infrastrukturu geoprostornih podataka (NIGP). Osnovni zadatak NIGP-a je da kreira integrisan sistem geoprostornih podataka, pritom omogućavajući korisnicima da lako pristupe različitim tipovima prostornih podataka, bez obzrira da li je njihov izvor lokalnog, nacionalnog ili globalnog karaktera (Vlada Republike Srbije, 2010, 1). Ovo naravno predstavlja ogroman iskrorak za različite analize ili usluge koje se zasnivaju na lokaciji, pogotovu ako se govori o pružanju značajnog broja javnih usluga.

Međutim, u RS, jedan broj službi koje se bave pružanjem javnih usluga ili ne shvataju u dovoljnoj meri značaj GIS-a za njihovo svakodnevno poslovanje, ili nemaju adekvatne kadrovske/tehničke prepostavke za integrisanje GIS-a u sopstvene aktivnosti - a u najvećem broju slučajeva je to kombinacija oba faktora. Naime, ako se govori o sektoru zdravstva, održavanju javnog reda i mira, odnosno radu spasilačkih službi, može se reći da je kod njih upotreba GIS-a za analitiku ili donošenje odluka u najbolju ruku i dalje relativno skromna, uz pojedine izuzetke. S druge strane, iako postoji koncept "gradskog GIS-a" čini se da lokalne uprave ne sagledavaju mnogobrojne mogućnosti GIS-a u smislu privlačenja investitora i stoga ne uspevaju da kreiraju dodatu vrednost za investitore upravo putem primene analitičke komponente GIS-a, mada svi uslovi za to postoje.

\section{PRIMENA GEOGRAFSKIH INFORMACIONIH SISTEMA U ZDRAVSTVU}

Duga i bogata tradicija prostornih istraživanja u zdravstvu seže do XIX-og veka (Setia, Singh, Mathur, Makkar \& Pal, 2017, 2). Veliki broj skorijih istraživanja koristi klasične alate za vizuelizaciju, kao i metode za ispitivanje podataka i njihovo modeliranje koje je preuzeto kako iz statistike, tako i iz epidemiologije. Paralelno sa studijama $u$ domenu prostorne epidemiologije, postojala su i druga istraživanja koja su bila manje u okvirima paradigme koja je svojstvena prirodnim naukama, a više u kontekstu društvenih nauka, uključujući, pre svega, istraživanja o zdravstvenoj neuravnoteženosti i varijacijama po regionima, pritom, ne uzimajući samo u obzir zdravstveno stanje, već i kvalitet dobijenih zdravstvenih usluga. Svakako, ono što je zajedničko za oba tipa istraživanja jeste spoznaja da su prostor i lokacija od izuzetnog značaja.

Svedoci smo da smo u prethodnih nekoliko godina izloženi sve češćim pojavama epidemija, ali i pandemija poput ptičijeg gripa ili A (N1 H1). Uzimajući u obzir da se tok svake epidemije može pratiti $u$ prostoru, evidentna je primena GIS-a u domenu poboljšanja javnog zdravlja i sprečavanja događaja koji mogu imati fatalne posledice po opšte zdravlje stanovništva, što je rezultiralo pojavom geomedicine (Blatt, 2015, 102), ali i prostorne epidemiologije.

Prostorna epidemiologija je analiza prostorne rasprostranjenosti rizika od bolesti ili incidence bolesti (Ostfeld, Glass \& Keesing, 2005, 328). Ovaj tip analize omogućava identifikovanje grupa stanovištva sa relativno visokim stepenom rizika za dobijanje određene bolesti i može značajno pomoći u izolovanju mogućih izvornih faktora bolesti za dalju analizu. Prostorne analize, takođe, mogu biti od velikog značaja i u slučaju nekih tipova bolesti koje nemaju epidemiološke korene, poput respiratornih bolesti 
ili raka. To je pogotovu tačno onda kada se slični rezultati potvrđuju u različito vreme i na različitom mestu, iz čega se mogu izvući određeni zaključci vezani za etiologiju neke bolesti (www.who.int, 2017).

Jedan od dobrih primera predstavlja i studija u kojoj su L. A. Williams, C. M. Ulrich, T. Larson, M. H. Wener, B. Wood, P. T. Campbell, J. D. Potter, A. McTiernan, i A. J. De Roos $(2009,373)$ istraživali koorelaciju između stanovanja blizu glavnih saobraćajnica i stanja imunog sistema. Studija se fokusirala na gojazne žene u postmenopauzi - dakle, populaciju koja je posebno ugrožena ukoliko je izložena zagađenju vazduha. Prilikom studije praćeno je pet parametara od kojih je najinteresantniji bio citotoksični limfocit koji konstituiše najbitniju komponentu urođenog imunog sistema. Citotoksični limfociti igraju značajnu ulogu u uništavanju tumora, kao i onih ćelija koje su inficirane virusima.

Rezultati studije su pokazali da žene koje žive do 150 metara od opterećenih saobraćajnica imaju 21\% manje citotoksičnih limfocita $u$ poređenju sa ženama koje žive dalje od frekventno korišćenih ulica. Autori ove studije smatraju da ovakvi rezultati mogu imati važne implikacije na buduću politiku utvrđivanja namene zemljišta blizu prometnih saobraćanjica. S druge strane, naredni korak koji bi mogao da se preduzme vezan je za kreiranje ciljanih kampanja fokusiranih na informisanje stanovništva koje živi blizu glavnih saobraćajnica o neophodnosti češćih zdravstvenih kontrola.

Još jedna interesantna primena GIS-a $\mathrm{u}$ domenu zdravstva je posledica brzog razvoja Interneta. Diseminacija geografskih karata u web okruženju može u velikoj meri pomoći donosiocima odluka pogotovu kada je u pitanju prevencija, kontrolisanje i reagovanje na pojavu određenih bolesti. Kao što je i predstavljeno $\mathrm{u}$ prethodnom primeru, fenomen bolesti je izrazito vezan za prostorne i vremenske faktore. GIS baziran na web-u omogućava da se raspoloživi podaci ne samo prikažu u realnom vremenu, već i da se na dimaničan način predstave najnovije informacije o bolesti na samoj karti. Stoga, ne čudi da je Internet u poslednjih 20 godina postao značajan medij za institucije javnog zdravlja, državne institucije koje se bave pitanjima stanja opšteg zdravlja, ali i stanovništva koje želi da dobije više informacija o javnom zdravlju. Gotovo se može konstatovati da je Internet tehnologija postala integralni deo nadzora javnog zdravlja.

Podaci o pojavi (i širenju) bolesti se više ne sapoštavaju isključivo putem zvaničnih izjava od strane državnih zdravstvenih institucija, već sve češće i putem manje formalnih kanala, koji obuhvataju od novinskih izveštaja, preko blog-ova i chat room-a, do statističkih analiza web pretraga. Svi ovi kanali zajedno daju jedan novi način sagledavanja sveopšteg zdravlja stanovništva koje se može značajno razlikovati od onog koje se prezentuje na uobičajen način. Ovim manje formalnim vidovima informisanja se duguje zahvalnost za skraćenje vremena neophodnog za spoznaju pojave bolesti, sprečavanje državnih tela da prikrivaju informacije o epidemijama, kao i za omogućavanje bržih reakcija na epidemije.

U skorije vreme javljaju se i nove hibridne web aplikacije koje mogu pretraživati, kategorizovati, filtrirati i predstaviti na karti sve aktuelnosti vezane za pojavu i širenje epidemija i drugih bolesti u realnom vremenu. Na primer, Health-Map je javno dostupan web portal (www.healthmap.org) za informisanje o javnom zdravlju, koji koristi podatke iz različitih izvora kako bi ponudio pregled trenutno prisutnih infektivnih bolesti i to na globalnom nivou. Izvori iz kojih Health Map prikuplja informacije o pojavi bolesti su različite pouzdanosti, varirajući od informacija koje se pojavljuju u okviru Google News-a, preko ProMED-a, do oficijelnih i provernih podataka koji potiču od Svetske zdravstvene organizacije. Ova web strana prikazana na Slici 1 ima i do 150.000 korisnika dnevno, uključujući državne zdravstvene institucije, doktore, ali i one koji se odlučuju na međunarodna putovanja. Drugi slični sistemi uključuju MediSys, Argus, EpiSPIDER, BioCaster i Wildlife Disease Information Node (Brownstein, Freifeld \& Madoff, 2009, 2154).

Interesantnu primenu prostorne epidemiologije razvila je kompanija Walgreens. Naime, kompanija je kreirala The Walgreens Flu Index ${ }^{\mathrm{TM}}$ koji se bazira na broju kupljenih lekova za suzbijanje gripa u preko 8.000 Walgreens-ovih apoteka širom SAD. Na osnovu 
broja kupljenih medikamenata na nedeljnom nivou se generišu karte koje prikazuju koji deo populacije je najviše izložen gripu i još bitnije, ukazuje na delove zemlje gde dolazi do pojave epidemije, brže nego što to čini američki Centar za kontrolu bolesti i prevenciju - čija je osnovna svrha da u najkraćem vremenu obavesti najširu javnost o zdravstvenim rizicima.

Međutim, GIS se ne koristi intenzivno u medicinskim krugovima samo za izučavanje epidemiologije, već i za predstavljanje svakog sistema koji ima prostornu komponentu, uključujući i pojave koje se odvijaju unutar tela samog pacijenta (ESRI, 2008a, 5). Ovo je posebno tačno u slučaju bio-medicinskih snimaka koji prikazuju organe na mikro nivou. Tako se, recimo, GIS baziran na vektorskim slikama može vrlo uspešno koristi za ispitivanje toka krvi u mikrovaskularnim mrežama (Roth \& Kiani, 1999, 44).

\section{PRIMENA GEOGRAFSKOG INFORMACIONOG SISTEMA U ODRŽAVANJU JAVNOG REDA I MIRA}

Službe koje brinu o javnom redu i miru (poput policije, sudstva i drugih relevantnih institucija) suočavaju se sa mnoštvom zadataka i izazova u svakodnevnim naporima da se osigura bezbednost stanovništva i njihove imovine. Uzimajući u obzir da gotovo svaki njihov zadatak i izazov ima geografsku komponentu, GIS se može smatrati bitnim resursom za svakodnevni rad ovih službi. Mogućnost brzog pristupa i procesuiranja informacija uz prikazivanje istih u prostoru omogućava odgovarajućim službama da alociraju neophodne resurse brže i efektivnije. Kod očuvanja javnog reda, informacije o mestu zločina, incidentu, osumnjičenom ili žrtvi su često od izuzetnog značaja u određivanju načina i obima reakcije. GIS se, takođe, može korisiti radi dobijanja informacija od kritičnog značaja za jedinice koje moraju u najkraćem roku odgoroviti na urgentne pozive. Danas se moderna policijska služba $u$ svetskim metropolama gotovo i ne može zamisliti bez upotrebe GIS tehnologija, koja im omogućava ne samo da brže reaguju na kritične situacije, već i da postignu najviši mogući nivo efikasnosti u korišćenju raspoloživih resursa (ESRI, 2006, 4).
Osnova svake analize počinje beleženjem tačnih mesta na kojima je došlo do ugrožavanja bezbednosti građana i njihove imovine. Na osnovu tih podataka možemo saznati dosta o tipu i učestalosti takvih događaja. Primer primene GIS u svrhe evidentiranja kriminalnih aktivnosti jeste "CLEAR Map" čikaške policije. Naime, Policijska uprava grada Čikaga je kreirala web portal (http:/gis.chicagopolice.org/) koji građanima može poslužiti kao pomoć za praćenje kriminalnih aktivnosti u njihovoj zajednici.

Ova web aplikacija, je javno dostupna i omogućava stanovnicima Čikaga da pretraže bazu podataka Policijske uprave grada Čikaga sa svim prijavljenim slučajevima narušavanja javog reda i mira. Aplikacija im omogućava da obave pregled tematskih mapa i tabela prijavljenih slučajeva i to prema vrstama nezakonitih aktivnosti. Sama baza podataka sadrži podatke za poslednjih godinu dana koji se mogu pretraživati u vremenskim blokovima od 90, 180, 270 i 365 dana, a svi podaci koji se nalaze u bazi se ažuriraju na dnevnoj osnovi. Putem korišćenja GIS software-a i drugih tehnologija, CLEAR Map-ova baza može generisati karte koje predstavljaju gotovo sve moguće kombinacije lokacija na kojima je počinjen zločin, odnosno, prikazivanje drugih relevatnih informacija, pri čemu svaka od njih može biti istog momenta projektovana kako u komandnom centru policijske uprave, tako i građanima na web portalu. Ovakvi vizuelni prikazi su korisna i efektivna dopuna u radu policijske službe, jer omogućava komandirima jedinica da u najkraćem mogućem roku identifikuju, prodiskutuju i ustanove trendove $\mathrm{u}$ domenu javnog mira i bezbednosti.

Vrednost ovakvog sistema iz ugla policijske uprave najbolje se može ilustrovati kroz slučajeve u kojima GIS pomaže da se na osnovu istorijskih podataka predvidi gde će se dogoditi sledeći prekršaj. Jedan takav primer predstavlja i slučaj iz 1998. u Los Anđelesu (Geggie, 1999, 111). Naime, detektivi su istraživali seriju od tri pljačke $u$ kojima je počinilac motorom presretao žrtve i pljačkao ih dok su išli ka svojim parkiranim vozilima. Pomenuti napadi su se dogodili na tri potpuno različite lokacije u krugu od nekoliko kilometara. 


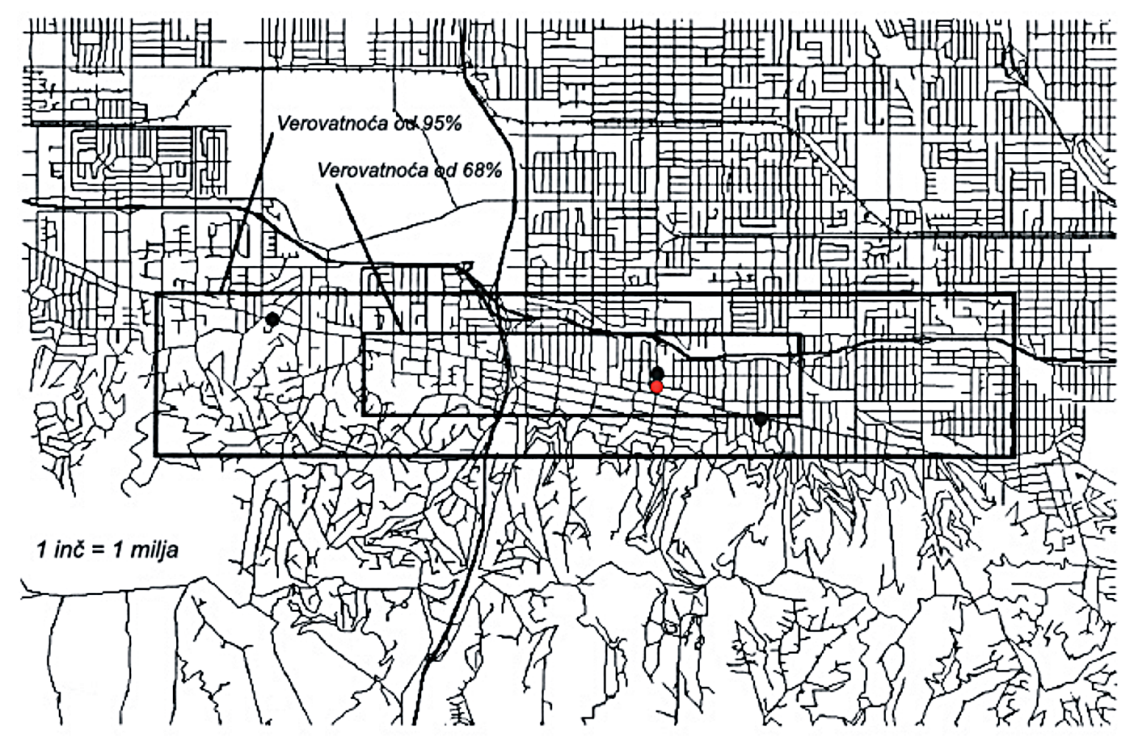

Slika 1 Mapa dela Los Anđelesa u kojima su izvršeni napadi

Izvor: Geggie, 1999, 112

Ideja je bila da se putem korišćenja istorijskih podataka i načina na koji je izveden zločin, predvidi što je bolje moguće vreme i lokacija sledećeg napada. To je i učinjeno oslanjajući se, pre svega, na statističku metodologiju koja koristi srednje vrednosti $(\mu)$ i standardnu devijaciju $(\sigma)$ uzorka. Ova metodologija je uzela u obzir vreme napada i lokacije na kojima su se napadi dogodili prikazani kao crne tačke na Slici 1. Polazeći od principa normalne distribucije - ustanovljeno je da postoji verovatnoća od 68\% (tj. unutar jedne standardne devijacije - $1 \sigma$ ) da će se sledeći napad dogoditi između 25. januara i 6. februara, u terminu od 20:45 do 23:45 na nekoj od lokacija koja je označena manjim pravougaonikom. Istom logikom, postojala je i verovatnoća od 95\% (unutar dve standardne devijacije - 2б) da će se sledeći napad dogoditi nakon dužih raspona u datumima, odnosno ,periodima dana, kao i na lokaciji koja je obuhvaćena većim pravougaonikom, prikazanim na slici 1 .

Četvrti napad se dogodio unutar svih vremenskih i prostornih okvira koji su predviđeni na osnovu prva tri napada. Nakon četvrtog napada, napravljene su nove procene $\mathrm{i}$ jedinice su raspoređene na teren $\mathrm{s}$ ciljem da uhvate osumnjičenog na delu. Prilikom pokušaja petog napada, osumnjičeni je uočen, ali je prilikom potere uspeo da pobegne. Iako je prestupnik pobegao, cilj je delimično postignut, jer nakon poslednjeg pokušaja napada, nije bilo sličnih incidenata u tom delu grada.

\section{PRIMENA GEOGRAFSKOG INFORMACIONOG SISTEMA KOD SPASILAČKIH SLUŽBI}

Spasilačke službe su odgovorne za zaštitu života i imovine, ali vrlo često raspolažu sa limitiranim resursima kako u ljudstvu, tako i u opremi. RS nije izuzetak. Naime, u RS postoji manjak vatrogasaca, pa umesto 7.000 vatrogasaca koliko bi trebalo biti, prema evropskim standardima, procena je da RS ima svega oko 3.100 vatrogasaca. 
Borba sa vatrenom stihijom je mnogo više od odlaska na samo mesto požara. Ona danas podrazumeva sveukupno razmatranje situacije i mogućih scenarija. GIS nudi skup alata za rad sa taktičkim, na lokaciji baziranim, informacijama poput onih šta se nalazi u neposrednom okruženju, a što može uticati na tok intervencije. U tom smislu urbane sredine predstavljaju poseban izazov (Forkuo \& Quaye-Ballard, 2013, 32). Objekti poput škola, tržnih centara, stovarišta opasnih materija, fabrika, benzinskih stanica, svaki na svoj način mogu dodatno komplikovati intervenciju na terenu i uticati na njen tok. Pristup ovim informacijama dok je interventna jedinica na putu ka lokaciji incidenta omogućava vatrogasnim službama da se rasporede brže i efektivnije, pritom sagledavajući moguće opasnosti kako za stanovništvo, tako i za jedinice koji intervenišu na terenu.

Naime, kako pristižu informacije, one se mogu pohraniti u GIS aplikaciju koja u realnom vremenu daje pregled potencijalnih opasnosti koje se nalaze u neposrednom okruženju (Slika 2(a)). Na primer, varničenje koje se može javiti u trafo stanici može doći u dodir sa zapaljivim gasom koji se širi i izaziva eksploziju širih razmera.
Vrednost ovakvog ,inteligentnog alata“ za vatrogasnu službu se ogleda i u tome što omogućava procenu broja ljudi koji žive blizu zone opasnosti. To je moguće na osnovu podataka iz popisa stanovništa koji su pohranjeni u bazu. Mada te procene neće posedovati apsolutnu tačnost, one omogućavaju planiranje određenih aktivnosti poput evakuacije delova grada. Ovde treba naglasiti da ovakav GIS omogućava brzu anticipaciju događaja i preduzimanje svih neophodnih mera za smanjenje, odnosno, eliminaciju neželjenih efekata po lokalno stanovništvo (Andrienko \& Andrienko, 2007, 901) (Slika 2(b)).

U ovakvim i sličnim situacijama jedna od najefektinijih strategija koja stoji na raspolaganju donosiocima odluka jeste evakuacija. Stoga, prisutno je izuzetno veliko interesovanje vatrogasnih službi (kao i drugih službi) koje je orijentisano ka stvaranju pouzdanih planova za evakuaciju. Ovo je imperativ, pre svega, $\mathrm{u}$ onim zajednicama gde postoje realne opasnosti od prirodnih katastrofa, poput zemljotresa, poplava, orkanskih vetrova, erupcije vulkana ili šumskih požara.

Dobra ilustracija je studija koju je sproveo T. J. Cova $(1999,53)$ i pritom razvio sistem za planiranje koji omogućava lokalnim zajednicama da ocene

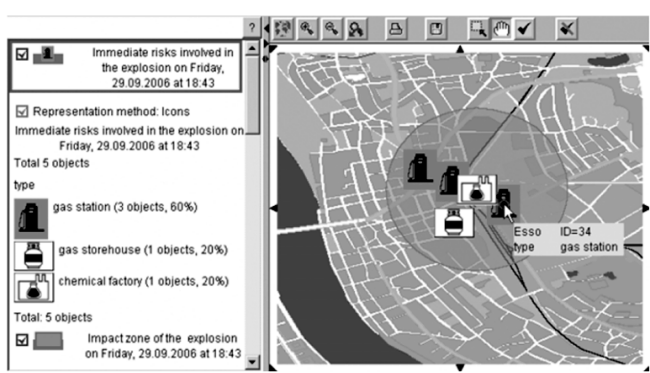

(a)

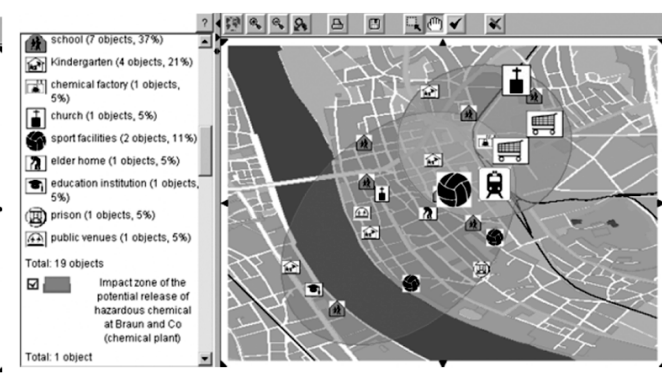

(b)

Slika 2 Prikaz potencijalnih opasnosti u neposrednom okruženju

(a) Karta pokazuje ostale potencijalno opasne objekte koji se nalaze u neposrednom okruženju;

(b) Karta pokazuje koji objekti će biti pod uticajem u slučaju da dođe do pojave nekog od mogućih događaja - konkretno, ispuštanja opasnih hemikalija iz lokalne fabrike 
verovatnoću za nastajanje problema prilikom procesa evakuacije. Aplikacija koristi banku podataka baziranu na GIS-u koja sadrži informacije o rasprostranjenosti stanovništa unutar zajednice, kao i mrežu ulica u tom kraju. Rezultat je karta "ranjivosti“ koja ukazuje na kritična mesta na kojima može doći do zastoja prilikom evakuisanja. Pošto se razmere katastrofe ne mogu unapred znati, metod radi po principu najgoreg mogućeg scenarija na datoj lokaciji.

Pretpostavimo da određenim delovima naselja preti opasnost od šumskog požara i da je evakuacija neophodna. Takođe, pretpostavimo da je samo jedno vozilo neophodno da se evakuiše čitava porodica iz jedne kuće. Ukoliko je kuća u slepoj ulici, onda svim domaćinstvima te ulice ostaje jedan izlaz iz ulice, i svi koji tu žive će ići ka tom izlazu. Odnosni metod radi tako što se sagledava čitava mreža ulica/puteva, kako bi se ustanovilo „usko grlo“ - tj. onaj deo puta koji će biti pod najvećim opterećenjem saobraćaja. U naselju sa gustom mrežom ulica/puteva, saobraćaj će se raspodeliti na nekoliko mogućih izlaza, umanjujući efekat „uskog grla”. Međutim, gusto naseljene oblasti sa samo jednim izlazom mogu biti izvor ozbiljnog problema prilikom evakuacije, ukoliko situacija zahteva brzu evakuaciju čitave te oblasti.

Na Slici 3 prikazana je karta dela grada Santa Barbara u Kaliforniji. Ulice su prikazane različitim bojama u zavisnosti od „uskih grla“, a na osnovu opisanog metoda (Cova, 1999). Ulicama su dodeljivane različite boje u zavisnosti od očekivanog broja vozila koja bi trebalo da prođu kroz kritična „uska grla“ prilikom evakuacije uzimajući u obzir najgori mogući scenario. Tamnom bojom su označena mesta kroz koja se procenjuje da će proći preko 500 osoba prilikom evakuacije, kreirajući potencijalno opasne zastoje, pritom oduzimajući dragoceno vreme.

Analizom ovakvih karata, vatrogasna služba (kao i druge službe spašavanja) mogu sagledati gde je najveća mogućnost da dođe do problema usled evakuacije i shodno tome planiraju razmeštanje svojih jedinica primarno $u$ tim delovima grada, kako bi ubrzale proces evakuacije. S druge strane, ovakve analize omogućavaju planiranje saobraćajne infrastrukture koja će uzeti u obzir "uska grla“ i pokušati da umanji njihov broj koliko je to moguće.

\section{PRIMENA GEOGRAFSKOG INFORMACIONOG SISTEMA U LOKALNOJ UPRAVI}

Jedna od najčešćih primena GIS-a se može naći u oblasti lokalne uprave (Campbell \& Masser, 1992, 529). Gradski menadžeri svakodnevno donose odluke koje

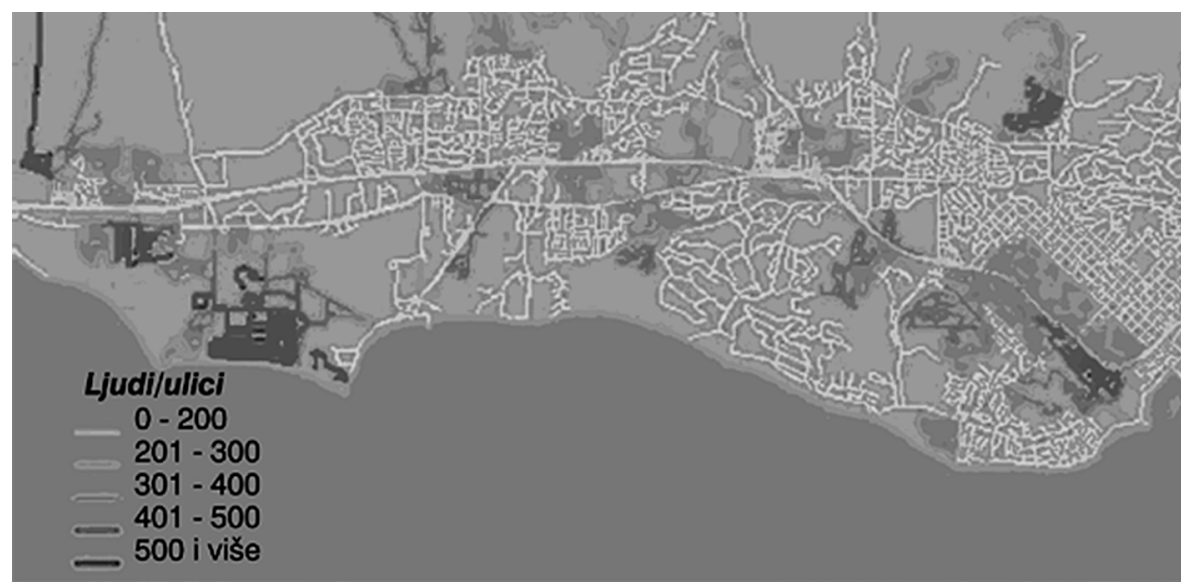

Slika 3 Karta uličnih „uskih grla“ za grad Santa Barbara, Kalifornija 
direktno ili indirektno imaju uticaja na kvalitet života svakog građanina koji živi i radi u nekom gradu ili zajednici. Međutim, danas su građani posebno svesni da pogrešne odluke donete od strane lokalnih vlasti mogu vrlo negativno da se odraze na kvalitet njihovog života - počevši od saobraćajnog kolapsa, pa do zaštite životne sredine. Stoga, građani sve češće zahtevaju da odluke donete od strane lokalnih funkcionera budu opravdane i potkrepljene adekvatnim podacima. Na taj način ne samo da se umanjuje rizik od donošenja pogrešnih odluka, već se predupređuje započinjanje nefunkcionalnih i često finansijski neopravdanih projekata.

Zapravo, građani sve češće zahtevaju da sve ono što se predloži za implementaciju rezultira povećanjem efikasnosti u rešavanju njihovih problema, generisanju održive vrednosti, daljem uvećanju razvojnih kapaciteta zajednice, kao i boljim upravljanjem gradskom infrastrukturom i resursima. Stoga, ne čudi da sve veći broj lokalnih vlasti (Jacoby, Smith, Ting \& Williamson, 2002, 305), ali i komunalnih preduzeća, na nivou grada investira u GIS, kao i u kreiranje baza podataka - čija sinergija može značajno da olakša donošenje odluka.

Činjenica je da su oni koji kreiraju politiku na lokalnom/regionalnom nivou oduvek imali dar da predlože krajnje složena rešenja. Pre pojave GIS tehnologija, trošak testiranja takvih rešenja i ocenjivanja njihove isplativosti sa aspekta vremena, napora i novca je bio visok. Faktički, GIS je omogućio da se kompleksna rešenja prvo testiraju putem niza scenarija na podacima iz realnog sveta, a tek onda i implementiraju nakon što je utvrđeno rešenje koje je prihvatljivo za sve stakeholder-e.

Sveopšta prihvaćenost GIS tehnologija upućuje na vrednost koju ovaj „alat“ ima za donošenje odluka. Naime, danas se GIS upotrebljava u gotovo svim aspektima planiranja razvoja jedne zajednice, odnosno, praćenja postojećih trednova u okviru nje. Gradskim arhitektama i katastarskim upravama su neophodne detaljne informacije o klasifikaciji zemljišnih parcela i raspoloživim zemljišnim resursima u pojedinim delovima grada ili regiona. Niskogradnja ima potrebu da planira mrežu puteva, definiše vremenske termine njihove izgradnje i predvidi sve troškove koji su vezani za njihovu izgradnju. Takođe, ne treba zaboraviti ni enormne insfrastukturne instalacije poput vodovoda, kanalizacije, gasovoda ili telekomunikacija - koje, svaka za sebe, zahtevaju prostorne podatke radi njihovog održavanja ili bržeg otklanjanja nastalih problema na mreži kao i preciznijeg planiranja i projektovanja novih kapaciteta.

Veliki broj institucija koje deluju na nivou javnog sektora prepoznalo je mogućnosti koje im GIS pruža. Neretko se zahvaljujući GIS-u vrše prostorne analize koje omogućavaju privlačenje novih investicija i podršku postojećim lokalnim kompanijama, koje zauzvrat kreiraju nova radna mesta, jačaju poresku bazu grada, ili se pak planira i upravlja implementacijom radova velikog obima.

Takođe, činjenica je da sinergija između sve dostupnijeg pristupa Internetu, s jedne strane, i digitalnih karata, $\mathrm{s}$ druge strane, definiše nove tipove i nivoe usluga koje lokalne vlasti mogu pružati svojim korisnicima. Generalno, usluge koje su bazirane na GIS tehnologijama koje mogu nuditi lokalne vlasti mogu se klasifikovati u sledeće tri kategorije: usluge orijentisane ka poslovnim korisnicima, usluge orijentisane ka lokalnom stanovništvu, i usluge koje su orijetnisane ka drugim organima vlasti. U radu će biti obuhvaćena samo prva kategorija.

\section{Usluge lokalne uprave orijentisane $k a$ poslovnim korisnicima}

Ovaj tip usluga se obično odnosi na pospešivanje ekonomskog razvoja, pružanje informacija o upotrebi zemljišta $u$ pojedinim gradskim zonama, efikasniju obradu različitih zahteva i brže izdavanje saglasnosti. Potencijalni investitori mogu pristupiti svim relevantnim informacijama 24 časa dnevno, zatim, mogu locirati delove grada u kojima je dozvoljena gradnja fabričkih postrojenja, tržnih centara ili poslovnog/stambenog prostora, te dobiti grafičke prikaze i analizirati demografske ili ekonomske podatke prikupljene iz poslednjeg popisa stanovništva za pojedine delove grada. 
U domenu pospešivanja ekonomskog razvoja, GIS tehnologija se koristi dominantno kao efikasan način za privlačenje novih investitora. Zapravo, može se reći da samo postojanje GIS-a na nivou jednog grada kreira povoljnu klimu za preduzeća koja posluju u oblasti visokih tehnologija. Međutim, da bi se privukao dodatni kapital, ili da bi se ubedili postojeći poslodavci da tu ostanu, GIS lokalne uprave mora biti prilagođen $u$ potpunosti poslovnim interesima krajnjih investitora. Za mnoge investitore, traganje za efikasnošću vodi ka nalaženju optimalne lokacije, i dobijanju transparentne slike o potencijalnoj lokaciji. Investitori danas žele da dobiju punu sliku uzimajući u obzir razvijenost saobraćaja i komunikacija, imidža zajednice, osposobljenosti lokalne radne snage, veličine tržišta, održivosti i planovima lokalne zajednice za dalji razvoj.

Stoga, da bi ostali konkurentni, mnogi gradovi (pa i čitavi regioni) razvijaju sopstvene GIS-ove koji bi trebalo da daju odgovore na sva ova, ali i mnoga druga pitanja budućim investitorima. Primer dobre prakse predstavlja Savannah Economic Development Authority (SEDA), koja je osnovana sredinom 1990-tih, s ciljem da poboljša životni standard žitelja koji žive u okruzima Savannah i Chatham, Georgia, SAD, putem stimulisanja ekonomskog razvoja kroz privlačenje investicija, otvaranja novih radnih mesta i pružanja adekvatne podrške preduzećima koja su već prisutna $\mathrm{u}$ tom regionu.

SEDA je, svakako, svesna da u konkurentskom okruženju koje je iz dana u dan sve oštrije, ne može jednostavno ponuditi potencijalnim investitorima list papira sa spiskom raspoloživih nekretnina i njihovim površinama. Investitorima je bitno da znaju gde se njihova potencijalna lokacija nalazi - koliko je daleko od luke, železničke stanice, autoputa ili lokalnog aerodroma. Povrh svega, investitori to žele da znaju čak i pre nego što naprave bilo kakav kontakt sa lokalnim vlastima.

Prepoznajući ove zahteve, SEDA je razvila GIS portal (http://www.savannahsitesearch.com/) sa bazom podataka raspoloživih proizvodnih hala, kancelarijskog prostora i parcela koje mogu biti od $500 \mathrm{~m}^{2}$ do 250 hektara. U svakom trenutku
SEDA raspolaže sa preko 150 aktivnih nekretnina. Potencijalnim klijentima SEDA daje na uvid sve raspoložive podatke putem Internet portala, ali i mnogo više od toga. Naime, upotrebom GIS-a omogućeno je povezivanje prostornih i neprostornih podataka kako bi se formirala efikasnija geo-baza podataka za upravljanje resursima, pritom skraćujući vreme pretrage. Klijenti mogu vršiti pretragu raspoloživih nekretnina, odabrati onu koja im najviše odgovara, a potom vršiti različite tipove demografskih i poslovnih analiza (ESRI, 2008b, 2). Uz to, SEDA ima mogućnost da evidentira sve novonastale promene za svega nekoliko minuta i tako svojim klijentima ponudi uvek ažurne i aktuelne podatke.

Studija o ekonomskom uticaju koji je SEDA imala na razvoj lokalne ekonomije, pokazala je da je između 1996. i 2007, u saradnji sa državnim i lokalnim partnerima, SEDA pomogla u stvaranju 15.320 novih radnih mesta i generisala 1,8 milijardi dolara $u$ investicijama (SEDA Annual Report, 2007). Takođe, ova studija je pokazala, da bi bez novih radnih mesta u čijem stvaranju je od ključnog značaja bila SEDA, regionu trebalo do 2020. da dostigne ovaj nivo razvoja.

\section{ZAKLJUČAK}

Primenom analitičkog GIS-au domenu pružanjajavnih usluga bavio se relativno mali broj istraživanja na našim prostorima, što predstavlja ključnu specifičnost i doprinos ovog rada. Rad kroz primere dobre prakse ukazuje na izuzetnu ulogu koju analitički GIS može imati za pojedine pružaoce javnih usluga, obzirom da veliki broj aktivosti koje one obavljaju svakodnevno i problemi sa kojima se suočavaju imaju izraženu prostornu komponentu. S druge strane, ne bi trebalo izgubiti iz vida da su pružaoci mnogih javnih usluga danas pod rastućim pritiskom da isporuče najbolju moguću uslugu što većem broju stanovnika i to sa ograničenim vremenskim, finansijskim, operativnim i ljudskim resursima. GIS - sa svojim analitičkim mogućnostima - predstavlja nezamenljivu tehnologiju koja im omogućava da planiraju i pruže javne usluge na način koji će poboljšati procesuiranje informacija, 
uspostaviti bolje procese za donošenje odluka, i sniziti ukupne troškove, pritom, unapređujući kvalitet života u njihovim zajednicama.

Svakako, jedan od najizraženijih nedostaka ovog rada vezan je činjenicu da ne daje precizniji uvid $u$ trenutno stanje u smislu korišćenja analitičkog GIS-a kod pomenutih pružaoca javnih usluga u RS. Naime, određene pretpostavke su učinjene pre svega na osnovu javno dostpunih podataka, što ne isključuje mogućnost da se neki vidovi analitičkog GIS-a koristi unutar pojedinih odeljenja pomenutih službi. Upravo ovaj nedostatak ukazuje na jedan od mogućih pravaca daljeg istraživanja, a to je ispitaivanje stepena integrisanosti i korišćenja GIS-a i njegovih analitičkih kapaciteta u svakodnevnom radu navedenih pružaoca javnih usluga u RS. Takvo istraživanje bi omogućilo daleko bolji uvid u postojeće stanje kada je u pitanju upotreba analitičke komponente GIS-a i identifikovalo dalje korake za intenzivnije prihvatanje ove tehnologije, sa krajnjim ciljem da se kreiraju nove usluge, odnosno poboljša kvalitet i transparentnost već postojećih javnih usluga za građane.

\section{REFERENCE}

Andrienko, N., \& Andrienko, G. (2007). Intelligent visualisation and information presentation for civil crisis management. Transactions in GIS, 11(6), 889-909. doi:10.1111/ j.1467-9671.2007.01078.x

Blatt, A. J. (2015). Geospatial Medicine. In Health, Science, and Place (pp. 101-110). Geotechnologies and the Environment, vol 12, Springer Cham. doi.org/10.1007/978-3-319-12003-4_9

Brownstein, J. S., Freifeld, C. C., \& Madoff, L. C. (2009). Digital disease detection-harnessing the Web for public health surveillance. New England Journal of Medicine, 360(21), 21532157. doi:10.1056/NEJMp0900702

Campbell, H., \& Masser, I. (1992). GIS in local government: some findings from Great Britain. International Journal of Geographical Information Science, 6(6), 529-546. doi:10.1080/02693799208901933
Coppock, J. T., \& Rhind, D. W. (1991). The history of GIS. Geographical information systems: Principles and Applications, $1(1), 21-43$.

Cova, T. J. (1999). GIS in emergency management. In P. A. Longley, M. F. Goodchild, D. J. Maguire, \& Rhind, D. W. Geographical Information Systems: Principles, Techniques, Applications, and Management (pp. 845-858). New York, NY: John Wiley \& Sons.

ESRI. (2006). Law Enforcement: GIS Best Practices. Redlands, CA, USA: ESRI Press.

ESRI. (2008a). Geography Matters. Redlands, CA, USA: ESRI Press.

ESRI. (2008b). Case Study: ESRI GIS Software Enables SEDA to Attract New Business to Savannah. Retrieved November 10, 2017, from www.esri.com/library/casestudies/seda.pdf

Forkuo, E. K., \& Quaye-Ballard, J. A. (2013). GIS based fire emergency response system. International Journal of Remote Sensing and GIS, 2(1), 32-40.

Geggie, P. (1999). Mapping and Serial Crime Prediction. In N. LaVigne, \& J. Wartell (Eds.). Crime Mapping: Case Studies - Success in the Field (109-116). Washington, DC: Police Executive Research Forum.

Haklay, M., Antoniou, V., Basiouka, S., Soden, R., \& Mooney, P. (2014). Crowdsourced Geographic Information Use in Government. New York, NY: World Bank Publications.

Jacoby, S., Smith, J., Ting, L., \& Williamson, I. (2002). Developing a common spatial data infrastructure between State and Local Government - An Australian case study. International Journal of Geographical Information Science, 16(4), 305-322. doi:10.1080/13658810110096001

Jovanović, V., Đurđev, V., Srdić, Z., \& Stankov, U. (2012). Geografski informacioni sistemi. Beograd-Novi Sad, RS: Univerzitet Singidunum i Univerzitet u Novom Sadu.

Longley, P., \& Batty, M. (2003). Advanced Spatial Analysis: the CASA Book of GIS. Redlands, CA, USA: ESRI, Inc.

Longley, P., Goodchild, M., Maguire, D. J., \& Rhind, D. W. (2001). Geographic Information Systems and Science. New York, NY: John Wiley \& Sons.Inc.

Ostfeld, R. S., Glass, G. E., \& Keesing, F. (2005). Spatial epidemiology: an emerging (or re-emerging) discipline. Trends in Ecology \& Evolution, 20(6), 328-336. doi:10.1016/j. tree.2005.03.009 
Roth, N. M., \& Kiani, M. F. (1999). A 'geographic information systems' based technique for the study of microvascular networks. Annals of Biomedical Engineering, 27(1), 42-47.

SEDA. (2007). Annual Report: Staff and Educational Development Association. Retrieved September 20, 2017, from http://www. seda.org/savannah/17/about-seda.html

Setia, S., Singh, S., Mathur, A., Makkar, D. K., \& Pal, V. (2017). Health care and Geomedicine: A Review. World Journal of Environmental Biosciences, 6(1), 1-3.

Vlada Republike Srbije (2010). Strategija uspostavljanja infrastukture prostornih podataka u Republici Srbiji za period od 2010. do 2012. godine. Preuzeto 24. decembar 2017, sa http:// www.geosrbija.rs
Voerkelius, U., Glavina, J., Specht-Mohl, C. i Schilcher, M. (2008). Upravljanje zemlišstem/ katastar u Srbiji-GIS priručnikza lokalne samouprave u Srbiji. Beograd, RS: Stalna konferencija gradova i opština, Republički geodetski zavod, Nemačka tehnička saradnja, Kancelarija za upravljanje zemljištem/ katastar u Srbiji.

Williams, L. A., Ulrich, C. M., Larson, T., Wener, M. H., Wood, B., Campbell, P. T., Potter, J. D., McTiernan, A., \& De Roos, A. J. (2009). Proximity to traffic, inflammation, and immune function among women in the Seattle, Washington, area. Environmental Health Perspectives, 117(3), 373-378. doi:10.1289/ ehp.11580

World Health Organization. Retrieved November 5, 2017, from http://www.who.int

Primljeno 4. decembra 2017, nakon revizije, prihvaćeno za publikovanje 22. decembra 2017. Elektronska verzija objavljena 29. decembra 2017.

Vladimir Senić je vanredni profesor Fakulteta za hotelijerstvo i turizam u Vrnjačkoj Banji Univerziteta u Kragujevcu. Predmet njegovog naučnog interesovanja je vezan za teme iz oblasti kvaliteta usluga, zadovoljstva i lojalnosti potrošača, i primene geografskih informacionih sistema u svakodnevnom poslovanju uslužnih preduzeća. 


\title{
THE USE OF GEOGRAPHIC INFORMATION SYSTEMS IN PUBLIC SERVICES
}

\author{
Vladimir Senic \\ Faculty of Hotel Management and Tourism, University of Kragujevac, \\ Vrnjacka Banja, The Republic of Serbia
}

With the further development of information and communication technology and a growing use of smart phones, the significance of Geographic Information System - GIS will indisputably continue to grow. This is supported by the fact that in the last decade geotechnology has been identified as one of the fastest growing technologies, along with biotechnology and nanotechnology. Even though GIS is increasingly being utilized in the Republic of Serbia, it appears that its use with some providers of public services is mainly deduced to showing spatial data with quite limited possibilities for a further analysis - which represents the essence of the use of GIS. The scope of this paper is to stress the outstanding analytical potential that GIS has in the domain of offering and improving various public services in the Republic of Serbia. The paper uses the examples of good practice in the sphere of the health system, public safety, rescue services and local government. The covered examples show that the use of the analytical component of GIS in everyday activities of the mentioned public services can make their work not only more transparent to the public, but considerably more efficient as well. This way, the analytical component of GIS enables decision-makers to improve the management of frequently limited available resources, while proving a higher level of the service quality to citizens as the final users.

Keywords: geographic information system (GIS), health system, emergency response, local government

JEL Classification: L80 